\title{
IMPLEMENTATION OF THE STRATEGY OF ENTREPRENEURIAL PRODUCTION OF LOCAL PRODUCTS
}

\author{
Dewi Nusraningrum \\ Faculty of Economics and Business, Mercu Buana University \\ dewinusraningrum@mercubuana.ac.id
}

\begin{abstract}
This is a public service activities related to the development of economic society through socialization and training on the implementation of the strategy of entrepreneurial production of local products. Problems that arise in the production of local products is the limitation of knowledge that caused local quality products are not able to compete in the market of national, regional and international level. In order to support the efforts of economic development of the community, training to make Aloe Vera shampoo to the community will help the community know how to produce a shampoo that can be used for family or for sale. These activities provide skills training strategy of production, so that the community is able to be independent and have the skills to make shampoo and develop strategies use Aloe Vera as a local product. These skills in addition beneficial for itself, it will at least help reduce the economic burden of families with income from local production are developed. The target of this activity are: (1) knowledge development strategy of entrepreneurial production on society. (2) the formation of a group of social entrepreneurship at the village of partners that are able to increase the income of local people in entrepreneurial activities of local products.
\end{abstract}

Keywords: Aloe vera, entrepreunership, local producst, production strategy

\section{INTRODUCTION}

Minister of Cooperatives and Small Entrepreneurs Coaching Numbers. 961/KEP/M/XI/1995 mentions; entrepreneurs are people who have the passion, attitude, behaviour and ability of entrepreneurship, entrepreneurship is the spirit, attitude, behavior and abilities as in dealing with the business or activities of which leads to the effort of finding, creating and apply this way of working, technologies and new products by improving efficiency in order to provide better service and or gain a greater advantage. To improve local product sales company must determine the right market to target your marketing efforts and determine the need and choice of target market.

Drucker (1959) stated entrepreneurship is the ability to create something new and different. To improve local product sales company must determine the right market to target your marketing efforts and determine the need and choice of target market. In the market the product is to be used the right strategy (Day \& Moorman, 2000). The strategy is an integrated action in the pursuit of competitive advantage. Proper marketing is formed from the right combination between quality, pricing, distribution channels and product promotion activities.

Quality improvement, as well as changes in designs and creates products markedly can provide stimulation to the consumer to purchase the product. Strategies to increase sales of local products is to improve the quality of local products, promoting local products, and determine the right marketing target. To improve the quality of local products by quality repair, repair characteristics, as well as improvements to the model. Next do a test market to find out the extent to which a product can meet the expectations of consumers and to ensure the future prospects through a sale in bulk.

Emulating the success of the city of Pontianak in West Kalimantan province which became one of the centres of production of Aloe Vera, and have made it as a commodity exports. Small and medium businesses in other regions could emulate the success of the city of Pontianak. Rawa Buaya Village Community that has the potential of entrepreneurial soul can develop its potential to support the improvement of economy in the region. Aloe Vera is one of the 10 best selling types of plants in the 
world that has been developed by developed countries like the United States, Australia and some countries in Europe. Processed Aloe Vera products vary greatly consisting of; crackers, jelly, chocolate, dry and wet cake, drinks, shampoo and SOAP.

The Aloe Vera plant can be consumed as snacks also has health benefits for the body and the skin including treating hair health. A problem that often occurs in the hair namely; hair loss, dandruff, tangled and coarse can be treated using Aloe Vera. Aloe Vera products be sold on the hair care market can be very expensive, thus cultivating the plant Aloe Vera on the terrace of the House will be cheaper and offer it into the hair care products naturally healthier. Aloe Vera can be extracted into a gel and can be used as a natural conditioner. Mix a half cup of Aloe Vera gel with 2 teaspoons of Hibiscus flowers. Homemade natural conditioner is said to be able to beat all the conditioner, and that will make the hair into lustrous and shining. Or made into nutritious herbal shampoo as hair care is practiced at this training.

Indonesia society in General who live in urban areas do not have the habit of planting Aloe Vera, so knowledge and motivation in the cultivation of the Aloe Vera plant is still low. The Aloe Vera plant is one that has many benefits for your health and does not require extensive land in order to grow and develop.

\section{METHOD}

The complexity of the problem of poverty was conceived Hendriawan (2003), not only concerning the low level of income and consumption, but also related to the low levels of education and health, powerlessness to participate in public decision-making, the inability of gives aspiration (voicelessness), as well as a wide range of issues concerning human development. In such contexts, especially in the aspect of education and human development, which leads to lower low levels of sensitivity about public whealth. Based on the above concept and the needs of the partners as well as the conditions and character of the partners, public service is intended to improve the knowledge and behaviour of the cultivation of the Aloe Vera plant for the community through improved skills and knowledge capacity of the community to be entrepreneurial.

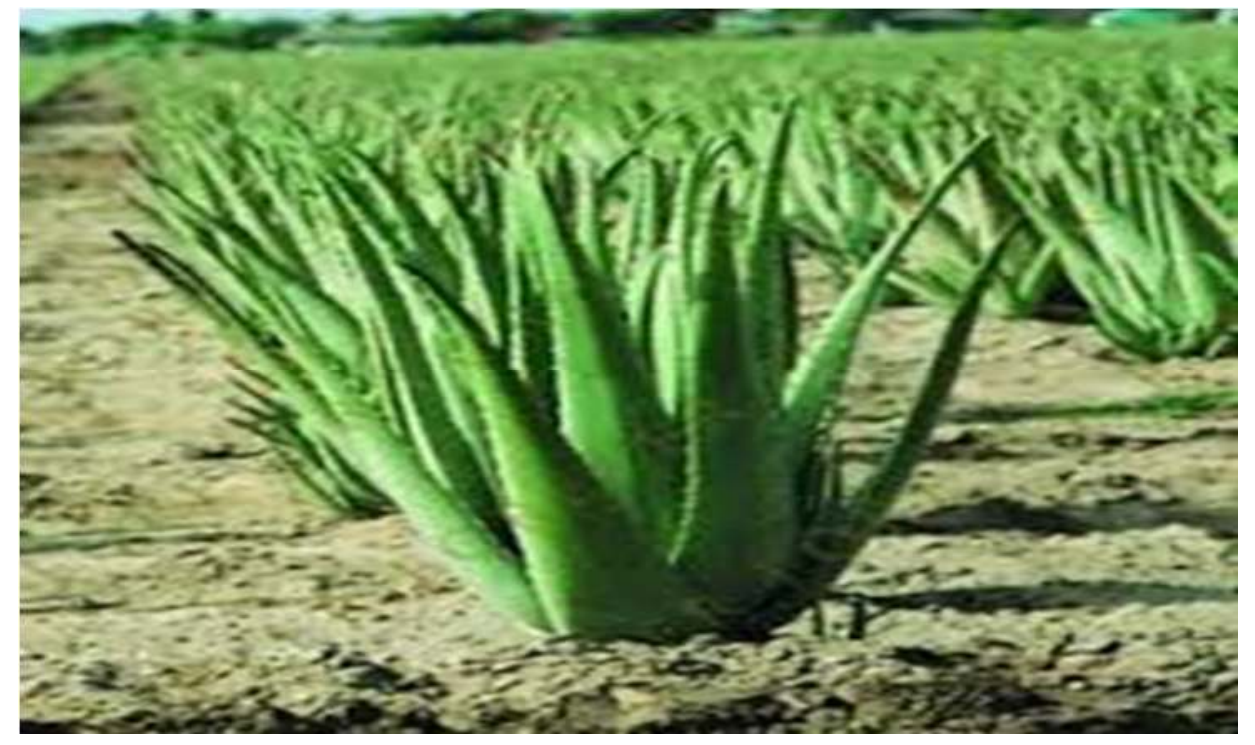

Figure 1. Aloe Vera

Training was given to explain the knowledge about the benefits of Aloe Vera plants and how to grow Aloe Vera in a narrow land, practicing how to make Aloe Vera shampoo, as well as how to be an entrepreneur. The benefits of Aloe Vera for hair loss, Aloe Vera because it allegedly stimulate hair growth by increasing the health of the scalp, balance $\mathrm{pH}$ levels and cleanse pores. It is said that anti- 
inflammatory, nourishing and soothing Aloe Vera that help stimulate new hair growth and helps to prevent hair loss. Ingredients Aloe Vera shampoo: Liquid Castile SOAP, Aloe Vera Gel, glycerin, vegetable oils, essential oils, measuring Cups, bowl, spoon, bottles, Funnel, towel.

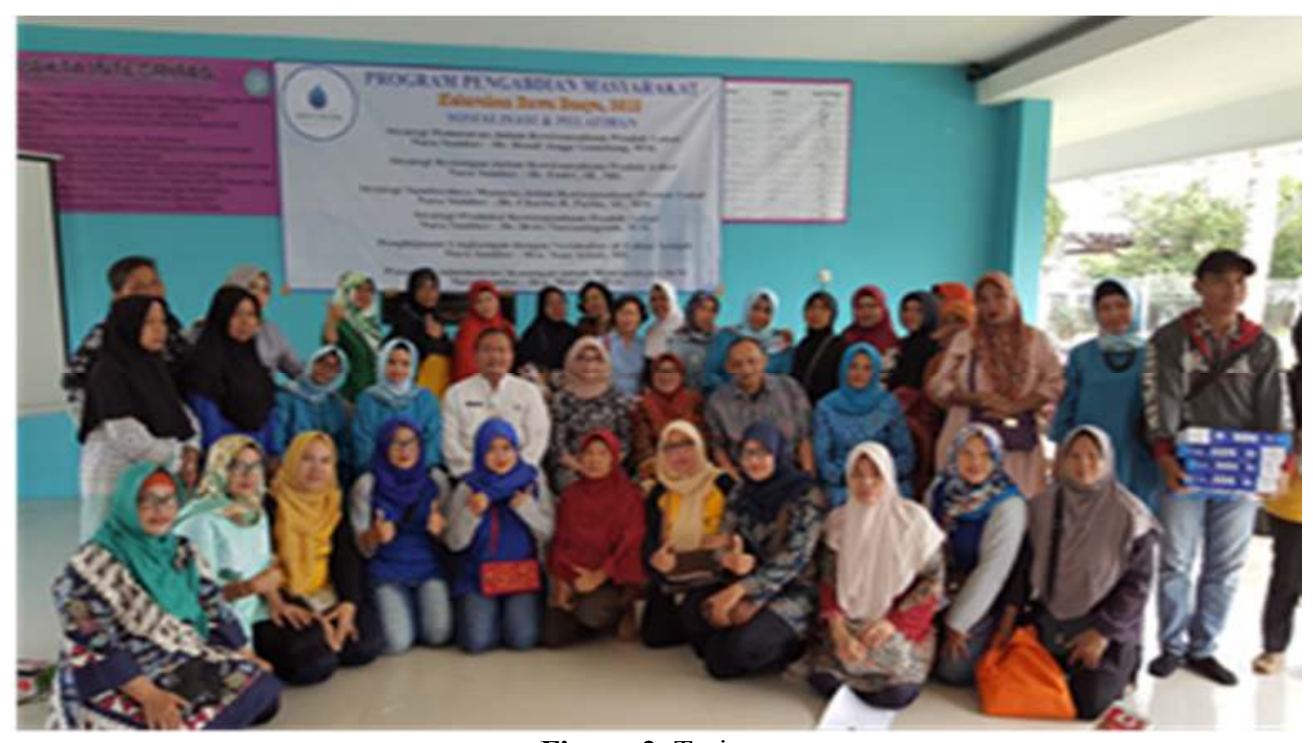

Figure 2. Trainee

How to make Aloe Vera shampoo: mix four ingredients together, measure out the 1/4 cup (60 $\mathrm{ml}$ ) each of Castile SOAP and Aloe Vera gel, 1 teaspoon $(5 \mathrm{ml})$ glycerol, and 1/4 teaspoon $(1 \mathrm{ml})$ of vegetable oil. Add each of the ingredients to the bowl and toss gently together with a spoon or whisk. Add a few drops of essential oil if desired. This mix makes about half a cup $(120 \mathrm{ml})$, but can be changed to make it more or less shampoo. Pour shampoo into pretty bottles using a funnel to avoid spilling. Store the shampoo at room temperatures and shampoo is ready for use for the purposes of the family or to be marketed.

\section{RESULT AND DISCUSSION}

Entrepreneurship is an attitude that is visible from the ability to create something new and unique so that it has value and can be beneficial to himself or others. So it can be said to entrepreneurship is the mental attitude and spirit of an active creative bercipta as well as powerless in developing business with the aim of increasing its revenue from activities performed. Entrepreneurship is a process of creating something new and make something different from the existing one, and aims to achieve prosperity for themselves and for the community (Kao, 2002). The strategy is the most important thing in developing businesses, especially when the efforts developed has just begun. A strategy is created based on the results of the analysis and the information obtained from the market. To run the new business, various types of strategy can be selected and applied in accordance with the capabilities of entrepreneurs, business conditions and the type of business that is developed. Local product strategy contains the destination of the product, target market, and the necessary budget.

The price is the value of a product which is a combination of the total cost of production and the level of profit that would like to obtain. For consumers, the price is an indicator of the value of the product that is the comparison between the value to products with a price level that is given or to be paid. Consideration in the price level of penetuan of them are internal factors (the company's marketing objectives, strategies, marketing mix and cost), external factors (the nature of the market and demand, competition).

A new product should be able to exert influence to the growth of the market, in addition to as much as mengkin to prevent a fierce competition, pricing strategies a new product there are two namely; skimming price was set higher prices than the average willingness to pay, typically at the time the 
product is in the stage of introduction of the penetration, price is set prices at a level that is relatively cheap or low at the beginning of the cycle the life of the product. The goal is to grab a larger share of the market and prevents the existence of competition or the entry of a competitor in the same effort. There are four forms of penetration rates in the price; price-controlled, prices elimination, promotion price, the price of the shield.

The market is a condition in which there is didalamya the whole potential customers who have specific needs or desires and which they are willing and able to engage in a process of Exchange in order to satisfy a need or desire such. In the strategy of an entrepreneur should be able to customize the market according to the characteristics of each so in the process of marketing the product and run business can run smoothly, the Division of the market called segmenting, targeting and positioning. Segmenting or segmentation is a step or action which is carried out by a seller or employers by means of community or consumer group into a perngkat-a device or entity according to the characteristics or specific traits in a market that's still compound into a homogeneous group or similar. Targeting is a step taken by a seller or entrepreneurs to determine which sections of the existing market segment and would like to enter with its products.

After consumers were divided into several groups or segments of a homogenous, subsequent action is to choose which groups of consumers who are thought to have advantages and opportunities of receiving the products offered and which are not promising market opportunities. After two Foundation product placement above done by a vendor or an entrepreneur then the last step entrepreuner can take to get a position in the mind of the consumer or thoughts that have been selected, so in this last step a seller or employers should direct all his ability to reposition their products in the eyes of the public as consumers of products.

Targeting is a step taken by a seller or entrepreneurs to determine which sections of the existing market segment and would like to enter with its products. After consumers were divided into several groups or segments of a homogenous, subsequent action is to choose which groups of consumers who are thought to have advantages and opportunities of receiving the products offered and which are not promising market opportunities. After two Foundation product placement above done by a vendor or an entrepreneur then the last step you can take is trying to get a position in the mind of the consumer or thoughts that have been selected, so in this last step a seller or employers should direct all his ability to reposition their products in the eyes of the public as consumers of them. Distribution strategy in General was a disbursing a good product in the form of goods or services to the place closest to the consumer. In the science of product marketing, distribution is one of the marketing function which can provide value to better against a product. Media promotion are the ways or means or tools used to make promotion, some means of promotion is; sales in person or online.

\section{CONCLUSION}

The first strategy should be planned is a strategy regarding the product, because that would be filed to the consumer or market is a product that is owned. In planning product strategy there are a few things that need to be analyzed, i.e.; analysis of the situation, the determination of the purpose of the product, the target market or product determination, the determination of the budget, the determination of the product strategy and the evaluation of the implementation of the strategy. For the community who wanted to be a successful entrepreneur needs to work hard and struggle as well as positive mental like dare to take risks, are capable of cooperation with others, honestly, responsibly and not easy to despair. Factors that determine the success of self-employment involves determination of the selected product strategy in accordance with the information obtained from the target market i.e. the existence of opportunities, qualified human resources, can market products produced, strong leadership, can organize a good job, be able to manage financial, planning, understanding Government regulations on business development and have a record of business.

Encourage consumers and Indonesia society to love and using domestic products, start realignment "ideology" and the politics of shopping by shopping at traditional markets. Training can be continued to help people who are in the territory of the Universitas Mercu Buana increase prosperity through the development of local wisdom. Implementation of the public service program that leads to increase in welfare of society could become a priority for educational institutions, government and industry. 


\section{REFERENCES}

Day and Moorman. (2010). Strategy from the Outside in: Profiting from the Customer Value. Wharton School. USA.

Drucker, Peter. (1959). Landmarks of Tomorrow. New York. Harpers \& Brothers.

Ha, Seong-Kyu. (2010). Housing, Sosial Capital and Community development in Seoul. Cities 27.

Hasbullah, J. 2006. Sosial Capital: Menuju Keunggulan Budaya Manusia Indonesia. Jakarta: MRUnited Press.

J. Mawardi M. (2007). Peranan Sosial Capital Dalam Pemberdayaan Masyarakat. Komunitas Jurnal Pengembangan Masyarakat Islam, Volume 3 Nomor 2.

Kao, Raymond W. Y. (2002). Entrepreneurism: A Philosophy And A Sensible Alternative For The Market Economy.College Press. USA.

Murray G. Ross and B. W. Lappin.(1967). Community Organization: Theory, Principles, and Practice. (Second Edition). New York: Harper and Row Publishers. 290 pp.

Tridico P. (2013). The impact of the economic crisis on EU labour markets: a comparative perspective. In: International Labour Review, Vol. 152. Retrieved from http://onlinelibrary.wiley.com/doi/10.1111/j.1564-913X.2013.00176.x/abstract. 